\title{
Insulin Receptor Substrate 4
}

National Cancer Institute

\section{Source}

National Cancer Institute. Insulin Receptor Substrate 4. NCI Thesaurus. Code C28476.

Insulin receptor substrate 4 (1257 aa, $134 \mathrm{kDa})$ is encoded by the human IRS4 gene.

This protein plays a role in co-localization of receptor tyrosine kinases with $\mathrm{SH} 2$ domaincontaining downstream signaling proteins. 